
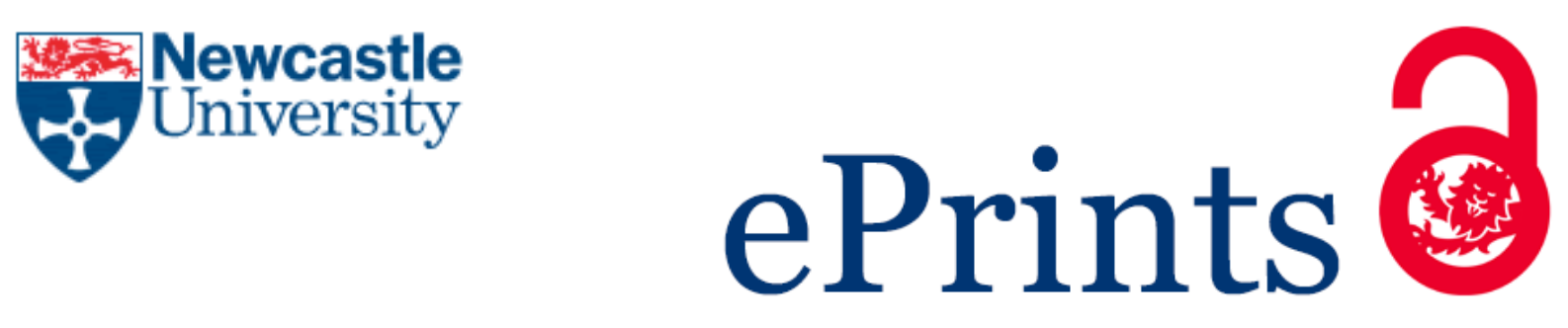

Islam DMZ, Jackson R, Robinson M.

European freight rolling stock fleet size in 2050 in light of the Transport

White Paper 2011.

Journal of Rail Transport Planning \& Management 2015, DOI: http://dx.doi.org/10.1016/j.jrtpm.2015.09.001

Copyright:

(C) 2015. This manuscript version is made available under the CC-BY-NC-ND 4.0 license

DOI link to article:

http://dx.doi.org/10.1016/j.jrtpm.2015.09.001

Date deposited:

$25 / 11 / 2015$

Embargo release date:

09 October 2016

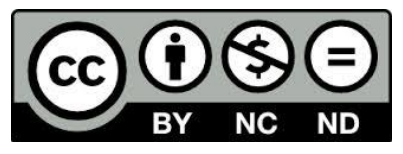

This work is licensed under a

Creative Commons Attribution-NonCommercial-NoDerivatives 4.0 International licence 


\title{
European freight rolling stock fleet size in 2050 in light of The Transport White Paper 2011
}

\author{
Author information \\ Dr Dewan Md Zahurul Islam* PhD, Freight Logistics Research Group, NewRail - Centre for Railway Research, \\ University of Newcastle Upon Tyne, NE1 7RU, UK, *Email for correspondence: dewan.islam@newcastle.ac.uk \\ and telephone: +44 1912083972 ; \\ Mr Ross Jackson MSc, Assistant Project Manager, Capita Property \& Infrastructure, North Tyneside, UK, \\ Telephone: 07808013273 (Mobile); Email: ross.jackson@capita.co.uk; \\ Prof Mark Robinson PhD, Director, NewRail - Centre for Railway Research, University of Newcastle Upon \\ Tyne, NE1 7RU, UK; Email: mark.robinson@ncl.ac.uk
}

\author{
Author information \\ Dr Dewan Md Zahurul Islam* PhD, Freight Logistics Research Group, NewRail - Centre for Railway Research, \\ University of Newcastle Upon Tyne, NE1 7RU, UK, *Email for correspondence: dewan.islam@newcastle.ac.uk \\ and telephone: +44 191 2083972; \\ Mr Ross Jackson MSc, Assistant Project Manager, Capita Property \& Infrastructure, North Tyneside, UK, \\ Telephone: 07808013273 (Mobile); Email: ross.jackson@capita.co.uk; \\ Prof Mark Robinson PhD, Director, NewRail - Centre for Railway Research, University of Newcastle Upon \\ Tyne, NE1 7RU, UK; Email: mark.robinson@ncl.ac.uk
}

\begin{abstract}
:
The European Transport White Paper 2011 sets high modal shift targets from road freight to rail 50\% by 2050. The objective of this paper is to determine the rolling stock fleet size and type up to the year 2050 and associated challenges for stakeholders. Considering the White paper targets, three scenarios are considered; a) Business as usual or Reference Scenario - extrapolation of current trends without major policy change; b) White Paper 2011 Low Scenario (WPL) based on a partial implementation of the modal shift targets and c) White Paper 2011 High Scenario (WPH) based on the full implementation of modal shift targets. To determine the future fleet size, the current paper also conducts a sensitivity analysis assuming $60 \%$ productivity level as a base line. The study finds, among others, that significantly more rolling stock (in particular flat wagons, covered wagons and covered hopper wagons) as well as improved asset utilisation will be vital to facilitate the transport of increased freight volume. Unified rail freight system starting with nine Rail Freight Corridors and cooperation among the rail freight operators, wagons manufacturers and companies involved in leasing and hiring wagons will be very important to achieve the modal shift.
\end{abstract}

Keywords: Rolling stock; Rail freight; Competitiveness; Modal shift; Europe; 2050

Paper type: Research paper

\section{Introduction}

The composition of freight transport chains in Europe has been changing in favour of road transport (Jackson, Islam, Zunder, Schoemaker, \& Dasburg, 2014) due to changes in production and consumption pattern (Hesse \& Rodrigue, 2004; Islam, Jackson, Zunder, Laparidou, \& Burgess, 2013). Factors such as internationalization, globalization, online shopping and home delivery and information systems (den Boer, van Essen, Brouwer, Pastori, \& Moizo, 2011; Hesse \& Rodrigue, 2004; Meixell \& Gargeya, 2005; Park, Choi, \& Zhang, 2009; Törnquist \& Gustafsson, 2004; Woodburn, 2007) have intensified this trend in last two decades. The effect of these factors is that the share of road freight has increased from $67.4 \%$ in 1995 to $71.6 \%$ in 2012 in terms of inland modes in the EU-28 countries. During the same period the share of rail freight has declined from $20.3 \%$ to 17.2\%. The downward trend for rail freight share began in 1970. Similar trends can also be observed for international rail freight transport services (European Commission, 2011, 2014b; SCI/VERKEHR, 2014; Törnquist \& Gustafsson, 2004). Flexibility, reliability, customer tailored and door-to-door service characteristics are behind the successes in the road freight transport sector (Islam \& Eidhammer, 2015; Jackson et al., 2014). An efficient and effective freight transport system, with alternative options in terms of service offerings and modes, is an important element in building a fit-for-purpose logistics system in a country or region (Bärthel \& Woxenius, 2004; Boyer, 2014; European Commission, 2011; Houldin, Clarke, \& Murphy, 2012). Within the freight transport domain, rail freight transport makes an important contribution to economic prosperity. In 
particular, its perceived environmental friendliness, and energy efficiency, ensures that it is within the focus of policy makers who would like to see rail play a greater role in European transport than it currently does (European Commission, 2011; International Transport Forum, 2013; Reis, 2014).

An important aspect of rail freight transport is the terminal-to-terminal offering which is a segment of a total transport service, offering complete door-to-door services involving multiple modal transfers and typically requires road haulage. In many cases the result is that rail freight services are unreliable and unattractive (den Boer et al., 2011; Krüger \& Vierth, 2015). The unreliability comes from its operational nature, status and response to modern logistics and supply chain demands. Until recently most of the rail freight operators in Europe were government owned and operated and in some instances this is still the case. These incumbents, larger than the private operators, have been operating fleets of rolling stock that are old with large parts of the fleet unaccounted for and/or in a dilapidated condition (Zunder, Islam, \& Mortimer, 2012; Zunder, Islam, Mortimer, \& Aditjandra, 2013).

The European Union (EU) Transport White Paper 2011 has set targets to significantly increase the use of rail freight transport in the future. In doing so, the White Paper aims to achieve a modal shift of $30 \%$ from road, to more sustainable modes such as rail, short sea shipping and inland waterways, by 2030 and a 50\% shift by 2050 , for distances greater than 300 kilometres (den Boer et al., 2011; European Commission, 2011). Den Boer et al. (2011) reports that $50 \%$ of road freight transport haul distance is longer than $350 \mathrm{~km}$. They also suggest that $60 \%$ of the European freight market share (in tonne-km) is over $300 \mathrm{~km}$. Bärthel and Woxenius (2004) suggest that intermodal road-rail service works best in freight transport markets for large flow over long distance. The breakeven distance of competing transport modes varies (Lu \& Yan, 2014). Due to the increased time required for rail freight transport modal transfers and the associated cost, risk of loss, damage and delay (Bärthel \& Woxenius, 2004; Danielis \& Marcucci, 2007; Yeo, Roe, \& Dinwoodie, 2008), the most cost-effective operations for rail freight services typically require a longer distance.

Cargo type and transport haul (distance), amongst others, are important determinants in terms of selecting transport mode options. This is due to necessary modal transfer that involves extra time, cost and risk of loss or damage to goods for an origin-to-destination transport service (Islam, 2014a). To offset this extra cost (and time $\&$ risk) element, longer transport haul is considered to favour rail and waterways transport, although a previous study suggests that road freight transport is effective in many cases for distances up to 500km (Jackson et al., 2014). They argued that the operation of rail freight services in a faster and more frequent nature allows rail to be competitive over distances of $200 \mathrm{~km}$ or more for low density, high value (LDHV) goods. With the white paper policy targets in mind, a recent study (Islam, Jackson, Zunder, \& Burgess, 2015) was conducted to better understand the impact of these objectives in terms of forecast freight volume. The study assumed three scenarios: a) business as usual (do nothing or Reference); b) partial implementation/achievement and c) full achievement of the modal shift targets. In line with policy implementation and freight forecast an efficient and effective rail freight transport system will need, among other things, an appropriate infrastructure, skilled operational management and an appropriate vehicle fleet size.

The objective of this paper is to identify the future requirements for rolling stock in 2050 for the EU27 through exploring the current state of the rolling stock fleet and its productivity level. The paper also gives thought to the challenges facing stakeholders of European railways. It identifies the challenges derived from the significant increase in rolling stock forecast resulting from various levels of white paper policy implementation, detailed in Section 3.

Section 2 of the paper presents a literature review of rail freight transport competitiveness and productivity. This is followed by a discussion on the research approach in section 3. Section 4 determines the current fleet size of European rolling stock using data from a variety of sources including: European (Eurstat) database (in section 4.1); Railway Directory (in section 4.2) and DNV (Det Norske Veritas) Report (in section 4.3). Section 5 estimates the future rolling stock fleet size and describes: rolling stock forecast assumptions (section 5.1); fleet size determination approach (section 5.2); determination of fleet size without changes in productivity level (section 5.3) and a sensitivity (higher or lower productivity levels) analysis examining the impact of increased productivity (section 0). Section 6 determines future wagon typology including wagon type requirements in 2050 (section 6.1) and the trend of rail cargo units in Europe (section 6.2). A Summary (section 7) is followed by Conclusions in section 8 . 


\section{Literature reviews on freight transport competitiveness and productivity}

A number of studies including those by the (Community of European Railway and Infrastructure Companies, 2014a; Luis Ferreira \& Murray, 1997; K+P Transport Consultants and Fraunhofer ISL, 2011; Pulfer et al., 2014; Salehi, Reinhold, \& Gasparic, 2009) suggest that increased productivity, using longer, faster and more frequent trains, will be one important way to increase rail's competitiveness.

Morlok, Sammon, Spasovic, \& Nozick (1995) believe that productivity in transportation refers to the ratio of transportation output to input or, in order words, the ratio of transport service output to the cost of providing the service. They also suggest that output can be measured in a variety of ways (e.g. total number of shipments delivered, the total tonne-km carried etc.). For the current research, the productivity of rolling stock is referred to in terms of its effective operational utilisation against availability over a period of time (e.g. year) and/or the extent of utilisation (i.e. how full or loaded is the rolling stock) while in operation.

UIRR (2013) suggests that the productivity of combined transport (CT), i.e. truck and trains, can be boosted by at least $30 \%$ by increasing train length and capacity. The report suggests 'maximum allowed train length and total weight is enabled to increase from $500 \mathrm{~m} / 1600 \mathrm{t}$ offering a P380 loading gauge to $750 \mathrm{~m} / 2000 \mathrm{t}$ with a P400 loading gauge along European Rail Freight Corridor 1 by 2019'. It is worth noting that opinion varies on what should be the maximum freight train length. For example although $825 \mathrm{~m}$ freight trains are in operation Germany, Lochma (2012) suggests that 'for conventional freight trains, train length may be increased to 750m on upgraded and new lines and to $1500 \mathrm{~m}$ if economic and technical feasibility allows it'. Additionally, recent trials with 1500m long Marathon freight trains in France (Marathon Consortium, 2014; Toubol \& Castagnetti, 2014) and the TEN-T regulations stipulate that, by December 2030, the railway infrastructure of the core network must fulfil requirements such as being 'fully compliant with the Technical Specification for Rail Infrastructure' and for freight lines 'the possibility of running trains with a length of $740 \mathrm{~m}$ '.

Productivity can be improved through various actions and measures such as: political reform to develop the business environment and the adoption of suitable regulations (Gwangwar \& Raghuram, 2014; Lochma, 2012; Salehi et al., 2009; UIRR, 2011; Zunder et al., 2013); higher utilisation of current capacity (Boysen, 2012a, 2012b; Morlok \& Spasovic, 1994); applying economies of scale (Rowangould, 2013); operation of rolling stock at higher speeds (L. Ferreira, 1997; Islam, Zunder, \& Zomer, 2010); operation of longer trains (Pulfer et al., 2014) (Gwangwar \& Raghuram, 2014) and technological changes (Bontekoning \& Priemus, 2004; European Commission, 2009, 2011). These aspects, linked to productivity improvement, can be seen in Figure 1.

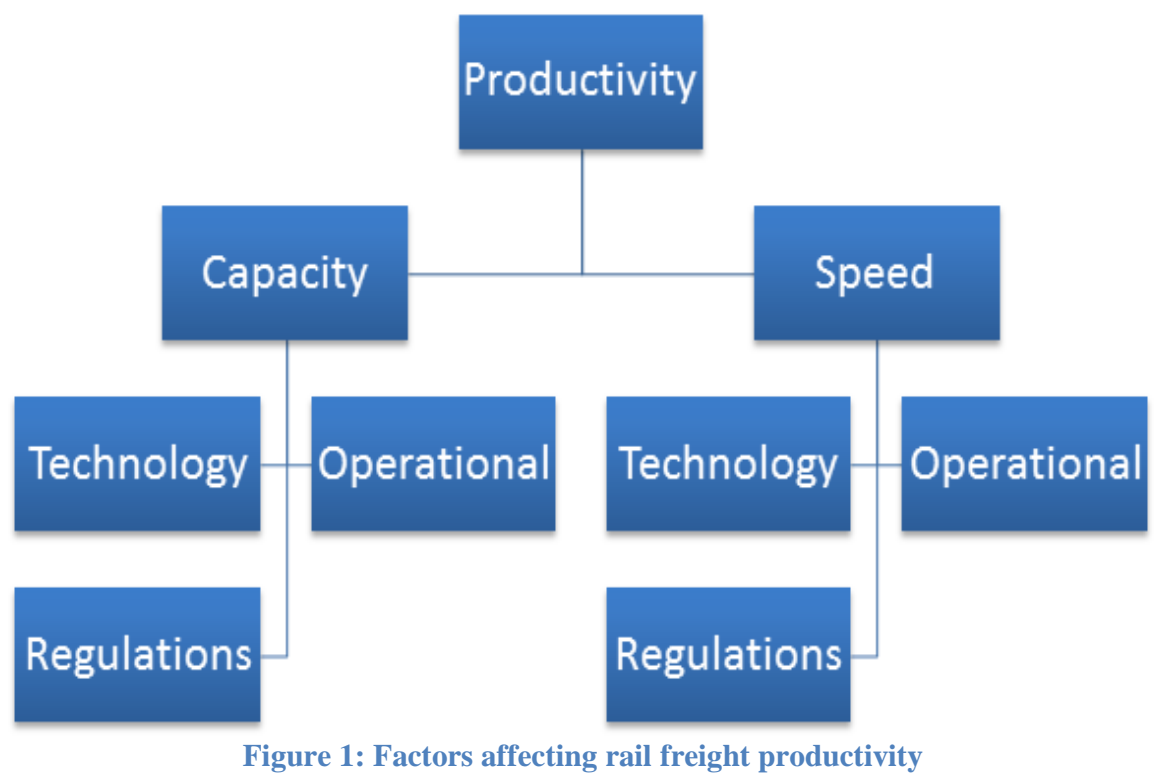

Several aspects are considered to relate to and indeed influence the future productivity of rail freight rolling stock. Capacity and speed are considered as the overarching parameters - each with associated technology, operational and regulatory aspects.

\subsection{Capacity}


An effective analysis of capacity is crucial for the evaluation of new investments as well as for an efficient management of the existing infrastructure (Malavasi, Molková, Ricci, \& Rotoli, 2014). Capacity is linked to better utilisation of the existing rail network and this extends beyond using additional trains in the timetable to carrying greater volumes of cargo and increasing capacity without additional services. Capacity could be increased through the better utilisation of existing vehicles, for example by reducing the time present at terminals or marshalling yards.

\subsubsection{Technology}

The current European wagons fleet are, generally speaking, of relatively high tare weight, meaning that rail freight can carry proportionally lower net freight - when compared to a vehicle with a lower tare weight. It is not unrealistic to anticipate that in the future, toward 2050; a reduction in the tare weight of the vehicles will be achieved resulting in an increased payload.

Marinov, Şahin, Ricci, \& Vasic-Franklin (2013) suggest that it is normal practice for freight trains to run on improvised schemes, i.e. freight trains are held in rail yards until they are full, meaning that they reach the train length limit and maximum weight (i.e. payload + tare weight). For some commodities the key is not the absolute weight limit of the wagon but the ability to offer the maximum cargo volume. This is especially true for goods with a lower density than those bulk cargoes traditionally transported by rail. It should be noted that in the U. S. there are already some innovations (e.g. WABASH National*) of this nature. By reducing tare weight, the net weight to gross weight ratio will be improved substantially to accommodate both weight and volume parameters. It is envisaged that a reduction in tare weight will be achieved through the trend toward light-weighting of the vehicle. It is thought this will be achieved through the use of more 'modern' and 'innovative' materials. Much attention is increasingly given to the operation of freight trains with higher axle loads of 22.5 tonnes in general (Community of European Railway and Infrastructure Companies, 2014a) and up to 30 tonnes for specific cases e.g. bulk traffic (Boysen, 2013; Mortimer \& Islam, 2014). This is not a widespread upper bound but has implications for track and structure strength to accommodate this weight level on a routine basis (Boysen, 2012a; Hilmola, 2008; Jackson et al., 2014).

Existing and commonly used vehicle bogies mean dynamic properties associated with higher axle loads contribute significantly to infrastructure damage. Advances in rail vehicle bogie and general rail vehicle dynamics through better suspension characteristics are envisaged to reduce the direct damage to track and allow for the permission of increasingly high axle loads (L. Ferreira, 1997; Fröidh, 2014).

Presently, rail freight wagons have a relatively long life span (typically $>25$ years) (Community of European Railway and Infrastructure Companies, 2014b), certainly when compared to rail's main competitor road transport. Whilst operators of such wagons will most probably point to a desire to increase this life cycle and therefore reduce the capital cost associated with the purchase of new equipment - it is considered by the authors that this desire is likely to have a detrimental effect on the overall productivity of the fleet. The comparatively short life cycle of road transport (typically $<7$ years for trucks) means the fleet continually benefits from product development. The fleet operators also naturally benefit from the reduced maintenance costs associated with a new vehicle.

Current European wagon fleets are non-flexible. To improve the load factor and ultimately to achieve higher productivity, the development of flexible (e.g. modular) designs of wagons is expected to contribute to the solution of this problem by providing much greater flexibility - for example, such wagons could be used for a wide variety of commodity types ranging from bulk traffic to inter-modal with options to change the application through the life of the wagons. This would be an innovative step forward and the rail sector would be required to take radical steps in design and certification if it were to achieve such ambitious goals. However, modular design alone could incorporate a range of cargo loading/discharge options in terms of apertures/door designs and cargo loading/securing systems. Commodity and application dependency need to be considered as part of the design process to maximise commercial competitiveness. It must be noted that costs of innovation are high (Wiegmans, Hekkert, \& Langstraat, 2007) which requires increased investment in the new and advanced wagons. The bigger question is who will benefit and who will bear the costs.

With this in mind, the EC has sought industry engagement through the SHIFT2RAIL funding mechanism. Shift to Rail (SHIFT2RAIL), a public-private partnership (PPP), will manage all rail-focused EU-funded R\&I activities. The SHIFT2RAIL initiative has a budget of EUR 920 million (M€) from 2014-2020, including an EU 
contribution of $450 \mathrm{M} €$ and a $470 \mathrm{M} €$ contribution from founding \& associated members. SHIFT2RAIL is a European technology initiative to seek focused research and innovation (R\&I) and market-driven solutions by accelerating the integration of new and advanced technologies into innovative rail product solutions. SHIFT2RAIL, with 5 Innovation Programmes (IP) and 5 cross-cutting themes, aims to promote the competitiveness of the European Rail Industry and will meet the changing EU transport needs. Through the R\&I carried out within this Horizon2020 initiative, the necessary technology will be created to complete the Single European Railway Area (SERA) (http://www.shift2rail.org/).

The future operation of rail freight is likely to require to an ensured transit security through the incorporation of security equipment. This will necessitate a link to track and trace and also fleet monitoring to maximise the wagon in service productivity. According to Regulation (EU) 1315/2013, Article 28, it is the responsibility of Member States to ensure that transport modes are inter-connected, not just physically in freight terminals but with the provision of information flows (European Commission, 2014e). For a reliable supply chain, the tracking and tracing of cargo and wagon is very important, particularly when delays or disruptions occur (Törnquist \& Gustafsson, 2004). An inter-operable tracking and tracing system (between rail operators and other modes) capable of providing real-time data along the supply chain is vital and one telematics information system on one out of nine Rail Freight Corridors (RFCs) is expected to make the operation more effective (European Commission, 2014e). Part of the design process should aim to minimise the incidence of wagon overloading and imbalanced loading leading to potential derailment.

Rail freight operation will have to differentiate between major generic traffic types (e.g. bulk/intermodal/general/tanker/hazardous). There can be a common core design of wagon to fulfil future requirements for most commodity categories and the transfer of more general cargo into inter-modal where required. Access to information on train services, schedules, available space and weight, pricing, terminal times and any pre/end haulage is vital. There will be suitable service information systems to maximise commercial in-service time. There will be positive implications for wagon fleet size, type and asset management.

\subsubsection{Operational}

Empty running is a very significant barrier to high productivity. This is applicable to both rail and road transport and has received attention from both. It is anticipated that there will be fleet management models and operations planning to maximise load factor and thus higher revenue (e.g. fewer wagons used much more intensively, reducing empty running) (Boysen, 2012a, 2014; Marinov et al., 2013; Woroniuk, Marinov, Zunder, \& Mortimer, 2013). This is likely to require significant changes in the measures of productivity and key performance indicators (KPIs) (e.g. loaded tonne $\mathrm{km}$ per annum/hours in service, hours available but not used/empty running, round trips per annum).

It is hoped that changes in operational patterns and higher frequency between trains will lead to an increase in productivity (Jackson et al., 2014; Shah \& Brueckner, 2012; Tsamboulas, Vrenken, \& Lekka, 2007; Woroniuk et al., 2013). At present this is rarely achieved since this operational pattern is expected to lead to the wholesale integration of freight and passenger rail services. Presently, priority and therefore higher quality train paths are given to passenger services by the infrastructure manager. Should such barriers be removed in part, rail freight is likely to be able to provide a much more reliable and punctual service.

\subsubsection{Regulatory}

There is a developing regime (European Railway Agency) for certification covering the design, manufacture, commissioning and deployment of new wagons and rolling stock in the EU (Community of European Railway and Infrastructure Companies, 2013; Zunder et al., 2013). Moves towards harmonization under interoperability should, theoretically allow designs to be capable of operation in pan European services (Community of European Railway and Infrastructure Companies, 2014a).

It is also worth noting that at present there is little incentive for rail freight operators and wagon owners to invest in potentially expensive wagon technologies (e.g. advanced suspension systems) that may for instance preserve or extend the life of rail infrastructure such as the track. One solution proposed is a change to current track access charging (TAC) methodologies to one that will reflect the detrimental effect (e.g. noise, damage to infrastructure) a rail vehicle is likely to have. This might also include: directly incurred costs aimed at recovering the full cost for infrastructure usage; societal costs such as a noise and scarcity charge (applying extra charges when a section of the network is congested). The direct usage tariff is comparatively simple and is charged per tonne-km (Community of European Railway and Infrastructure Companies, 2014a; Link, 2004; Nash, Nilsson, \& Link, 2013). The Netherlands for example have already introduced the noise-differentiated 
track access charge (Community of European Railway and Infrastructure Companies, 2014a; Department for Transport, 2011).

With this in mind, if rail is to explore markets currently unexploited such as the transport of lower density high value goods where capacity is filled by volume rather than weight, changes are required to charging methods to facilitate lighter vehicles. Unfortunately while some EU states (such as Germany, the UK and Switzerland) have comprehensive track access charging models, others do not. A comprehensive TAC may include tariffs comprising a base charge (e.g. up to $\leq 22.5$ tonnes axle load vehicle) plus a differentiated (for varying rolling stock characteristics) charge on, for example, heavy freight vehicles (e.g. for $\geq 25$ tonnes axle load). The justification of a higher charge is that the heavier vehicle will cause more damage to the track. The tariff may include a performance aspect charge to the operator (i.e. charge for delayed operation of freight trains) as well as a performance charge on the infrastructure manager to ensure a safe and reliable network. With this in mind a rail freight operating company is unlikely to operate a non-compliant wagon in a country with a comprehensive charging system. Rather, they are likely to avoid those countries and continue to operate elsewhere and subsequently impact negatively on the infrastructure of that country (which might have a less comprehensive track access charging model). Recent analysis of a German model with a focus on "unbundling, public infrastructure financing and access charge regulation" (Link, 2012) found that this regulation ensured transparency in access to the network. Access charges for network usage strengthened the position of the regulator and moved the current ex-post regulation towards an ex-ante regulation based on the efficient costs of service provision.

\section{$2.2 \quad$ Speed}

\subsubsection{Technology}

Troche (2005) suggests that automatic coupling allows faster coupling and uncoupling of rolling stock. It is envisaged that, vehicle performance is likely to increase toward 2050 in terms of overall top speed as well as acceleration and deceleration (Community of European Railway and Infrastructure Companies, 2014a; Fröidh, 2014; SUSTRAIL, 2015). The light-weighting of vehicles has previously been mentioned as a method by which payload may be increased. Additionally, the light-weighting of rail vehicles will also impact positively on the ability of the vehicle to increase top speed or actual (not theoretical), acceleration and deceleration properties (Community of European Railway and Infrastructure Companies, 2014a, 2014b; SUSTRAIL, 2015).

It is anticipated that there will have to be significant improvement in rail vehicle braking systems, for example, through the usage of disc brakes to minimise noise and enhance braking performance (SUSTRAIL, 2015). Currently Pneumatic (air) brakes are used which are time consuming for stopping and deceleration and which generate higher levels of noise. An intermediate solution, achievable by 2030, would be to fit silent brake blocks such as Radio Controlled EOT (end-of-train) valves. These could then be replaced by 2050 with high performing, fully electronic Electro-pneumatic brakes (EP), (Capacity4Rail Project, 2014). The EP allows for faster as well as multilevel braking from mild to severe brake applications, as the electronic control signal is propagated instantly to all of the rolling stock of a freight train. In contrast, the change in air pressure that activates the brakes in a conventional system takes several (20-30) seconds to propagate fully from front to rear of the train and thus is not conducive to longer freight train operation as it causes significant compressive forces between the wagons resulting in potential train derailment (Capacity4Rail Project, 2014). An alternative to reducing noise levels would be a step change from cast iron brakes, which cause: quicker deterioration of wheels; rough wheel surfaces and high noise levels, to composite material brakes (Clausen et al., 2012). The DNV Study (European Railway Agency, 2011b) recommends for a gradual introduction of silent brake and automatic coupling in new rolling stock.

The cost of this type of braking technology is such that the possibility to retrofit to existing wagons may not be attractive and that any use of disc brakes should be considered for new-build vehicles. The SPECTRUM project explored braking systems for both quicker acceleration and deceleration (SPECTRUM, 2012). The higher acceleration and potentially top speed of trains requires a compensating capability to slow to a stop including full emergency braking under maximum load conditions (SPECTRUM, 2013). The higher cost of electric brakes can be offset by the requirement for reduced maintenance over the potential life of the vehicle. There is also the potential to incorporate brake and train control lines into the wagons at construction for short haul and push pull fixed formation train operations if this operational method is required for some traffic applications.

It is likely that in 2050 there will be reduced rolling resistance through the increased usage of roller bearings resulting in minimal axle box lubrication over the vehicle life. An extension of maintenance intervals can be achieved through design and component capability. Under this system, the maintenance costs of wagons could 
be identified and lowered by: intelligent design; material selection and coatings plus the recognition of wagons as a vital and expensive asset base to be managed intensively.

Increased speed would be achievable with the newer track friendly (low track force - LTF) bogies and suspension systems (SUSTRAIL, 2015), though these are currently more expensive than the traditional three piece bogie which is a much older design and has major known deficiencies particularly at higher speeds. LTF bogies may offer (where applicable) significant benefits in terms of track access charges and also comparable ride qualities to road freight for those commodities that mandate better ride qualities as part of a broader service and product package. The freight train will be in operation at higher speeds for inter-modal and high value time sensitive traffic. A comprehensive evaluation, for example Life Cycle Cost (LCC), of such solutions are vital. The LCC is a tool to determine the most cost-effective option amongst competing alternative options, for example used in SPECTRUM study (Jackson, Matsika, Zunder, \& Mahler, 2013).

\subsubsection{Operational}

Operational speed is paramount to the success of rail freight in the future, whilst increasing attention is given to technological changes that allow for faster point to point speeds (Community of European Railway and Infrastructure Companies, 2013; SUSTRAIL, 2015). Higher operational speed frees up capacity that can accommodate more trains on the network (Nelldal \& Boysen, 2012). However if the overall operational time for origin-to-destination transport haul is not reduced, advances in this area (i.e. rail terminal to terminal) are likely to be mitigated. Operational speed should therefore extend to time and access to terminals where it is hoped innovative transhipment techniques will reduce the time spent at terminals and hence the overall operational speed. There are pressures to increase the axle load of certain types of wagons, particularly those employed in bulk traffic applications and any increases may be on specific lines or routes and not part of a general increase in axle weight ratings across the entire network. The corresponding requirement to enhance coupler strength and braking to accept the new higher gross weight ratings will need to be accommodated at the design phase.

\subsubsection{Regulatory}

There will be large scale rail loading gauge enhancements (high cube) to maximise wagon and container size.

The anticipated desire to increase speeds and vehicle performance toward 2050 is likely to have significant implications in terms of regulation. Currently there exist more stringent regulations for passenger vehicles, clearly in place with the safety of passengers in mind. However, as the anticipated rail freight vehicle speed (toward passenger standard) increase is realised more stringent regulations are likely to follow. High performance freight vehicles are expected to have to adhere to passenger regulations.

\subsection{Other}

Here a number of measures are considered which do not necessarily fall within the categories of capacity or speed. There will be increasing commercial and emissions limits on road transport together with access limits relating to time, size, weight and fuel type including rising fuel costs. Some of these same pressures impact rail, particularly in relation to fuel, although this is mitigated by electrification. Noise constraints, are also an issue rail will need to address through design and the replacement of noise generating components such as brakes discussed in section 2.2.1. Such improvements would potentially create a greater market opportunity for rail in specific sectors and commodity flows by 2050 .

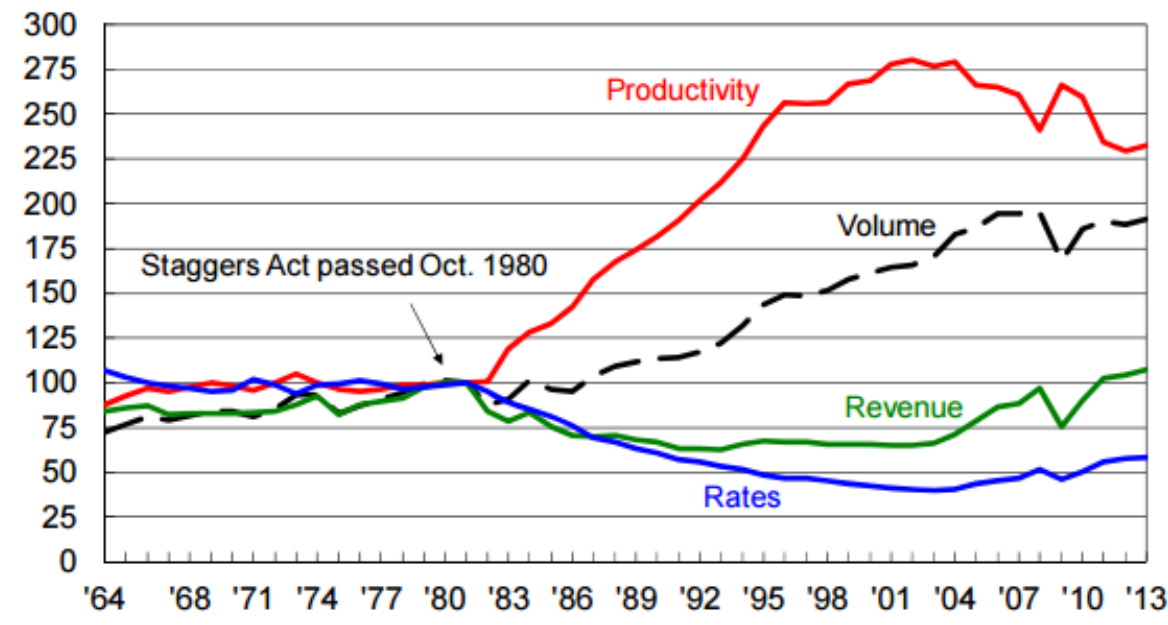

Figure 2: U S. railways performance since Staggers Act 1980 (1981=100) (AssociationofAmericanRailroads, 2014) 
Rail freight transport in the United States (U. S.) has performed much better than that in Europe. Figure 2 shows that productivity has an important role in increasing or attracting higher cargo volume as well as offering lower freight rates to customers. An important point which clearly emerges is that suitable rail freight reform (like the Staggers Act of 1980 for U.S. railways) is at the heart of a competitive rail freight market. The Association of American Railroads (2014) explains that the decline in productivity in recent years is mainly due to the effect of higher fuel prices in the productivity calculation.

In comparison, since 1991, the EU has worked hard to transform the government owned and operated European railways into a commercial one. For example, it has implemented many Directives (such as 91/440/EEC) and three reform packages such as the First, Second and Third Railway Packages (Islam \& Eidhammer, 2015; Zunder et al., 2013). A recently adopted Fourth Railway Package aims to open up closed markets to private rail operators and cut ties between infrastructure managers and incumbent rail operators (Kallas, 2013), but due to objections from a number of key Members States, its 'water-downed version' was approved unwillingly by the European Parliament (European Commission, 2014f; Kallas, 2014). Despite these efforts and as discussed in Section 1, rail freight volume and share has declined, not increased. Islam and Eidhammer (2015) strongly argued 'for positive European rail reform that will make a real change, similar to, but not identical to the Staggers Rail Act in the U. S'. The current research also reiterates the argument.

The current research expects that if some or all of the discussed measures be taken or technologies implemented leading up to 2050, rail freight is likely to increase its productivity and therefore market share. From the above discussion it can be seen that rolling stock volume or fleet size and productivity are intrinsically linked, suggesting that an increase in productivity will produce an equal increase in freight cargo volume. The current research assumes in addition to the necessary investments in infrastructure and rolling stock by the railway industry actors, the European Commission and Member States will continue their efforts of reforming the European railways and an appropriate liberalisation measure will be in place to make the freight transport market truly competitive (in particular with road in terms of cost, transit time, reliability, among others), efficient (do more with less and scarce resources) and productive (e.g. by higher wagon utilisation) by 2050 . To be truly competitive, the European rail freight market must be open and resist a monopoly or near monopoly situation where the market is dominated by a single operator. In this market the rail freight operators will need appropriate rolling stock and the remainder of this paper will focus on ascertaining the type of rolling stock fleet required by 2050.

\section{Research approach}

Efficiency of a system can be understood as the ability to produce a desired result by avoiding wastages of materials, energy, efforts, money, and time etc. An efficient freight transport system can move more cargo with less freight rolling stock, for example, by proper planning for asset utilisation. In the European context, an efficient and sustainable transport system is frequently referred to (European Commission, 2011) in the sense that the transport system will be resource efficient and will produce less emissions (Psaraftis, 2015). Within the resource efficient transport system, different (intra- and inter-modal) operators, for example rail freight operators compete with road operators to offer best service, in terms of, for example, reliability, cost, time etc. to their customers (Woroniuk et al., 2013). To improve competitiveness, different operators may adopt different strategies and measures such as use of advanced technology (Tsamboulas et al., 2007) in new (that may incur higher per unit operational cost) versus old (less costly) freight rolling stock.

The research applies both qualitative and quantitative methods. The qualitative research includes reviews of literature (Official Journal of European Union, 2013; UIC, 2001, 2004a, 2004b, 2011) in the rail freight transport system in Section 2. It also includes data collection, for example, from publications on the wagon typology by the International Union of Railways - UIC and wagon type then assigns them with a corresponding NSTR (Nomenclature uniforme des marchandises pour les statistiques de transport) (ten: 0 to 9) number which categorizes commodity types (see Table 1 ). 


\begin{tabular}{|l|l|l|l|}
\hline NSTR Commodity & NSTR No. & Primary Wagon Type & Alternative Wagon Type \\
\hline Agricultural products & 0 & Covered Hopper Wagons & Open top wagons for some products \\
\hline Foodstuffs & 1 & Covered Wagon & Flat Wagon (Refrigerated Container)/tanker \\
\hline Solid mineral fuels (Coal) & 2 & Open Top Wagons & Covered hoppers \\
\hline Petroleum products & 3 & Tank Wagon & Container flats for tank containers \\
\hline Ores and metal waste & 4 & Open Top Wagons & Covered hoppers \\
\hline Metal products & 5 & Flat Wagons & Covered wagons \\
\hline $\begin{array}{l}\text { Crude, manufacturing, } \\
\text { building materials }\end{array}$ & 6 & Open Top Wagon & Flat Wagon, Covered Wagon, Tank Wagon \\
\hline Fertilizers fragons \\
\hline Chemicals & 7 & Covered Hopper Wagons & $\begin{array}{l}\text { Tank or hopper } \\
\text { granules/powders/liquids }\end{array}$ \\
\hline $\begin{array}{l}\text { Machinery, } \\
\text { equipment }\end{array}$ & 8 & $\begin{array}{l}\text { Tank Wagon/ Hopper Wagon } \\
\text { for gases/granules }\end{array}$ & $\begin{array}{l}\text { Flat wagons for container tanks, hoppers for } \\
\text { granules, powders, gases and liquids }\end{array}$ \\
\hline
\end{tabular}

Data source: The authors

We determined the rolling stock fleet size for 2010 as a base year using data from Eurostat, the Railway Directory, and the DNV report. The fleet size for a year is calculated using average annual growth rate, assumed from previous study Islam, et.al. (2015) for a scenario, multiplied by the fleet size in previous year. Reviewing the collected Eurostat data, we found that the total rolling stock fleet declined between the years 2001 and 2009 for most European countries (except Austria, Estonia, Latvia and Lithuania) and the decrease is small for some countries such as Finland but significant for other countries such as Belgium and Romania. There was data missing from some countries which are significant in terms of rail freight operation such as Germany, France, and the UK and to overcome this problem we calculated an average increase or decrease of all the individual countries and then an overall increase/decrease for the year 2009. Using this average increase/decrease, we fill up the missing data that gives us a new table with rolling stock data for 2009 (discussed in detail next section). In the case of calculation of rolling stock fleet size from Railway Directory, we have compiled data retrieving data manually using their website, Railway Directory 2007 and 2011(further discussed in the next section). In the case of DNV report, we used fleet size from the report, explained in the next section.

To forecast rail freight volume in tonne-km up to 2050, previous research (Islam et al., 2015) used the freight model TRANS-TOOLS able to assess elements such as sequential trade, identifies modal split and logistics modules, and is able to forecast transport demand up to 2030. Beyond 2030, meta-models supported demand projections up to 2050 using trend extrapolations. The current research used this freight forecast as input to determine the rail freight rolling stock fleet size and type requirements up to 2050. As in the forecasting scenarios (Islam et al., 2015), the current research applies three scenarios: a) Reference Scenario (REF) extrapolation of current trends without major policy change; b) White Paper 2011 Low Scenario (WPL) - based on a partial achievement of the modal shift (30\%) targets, and c) White Paper 2011 High Scenario (WPH) based on the full realisation of the modal shift (50\%) targets. For each scenario, three types of analyses have been conducted, namely: NSTR cargo types with the highest anticipated growth; NSTR cargo types with the highest volume, and top 10 origins - destinations country pairs (routes). From the deliverable 'Rail freight forecast up to 2050' (D-RAIL, 2012a), annual growth rates of $1.26 \%, 1.66 \%$ and $2.92 \%$, for the REF, WPL and WPH scenarios respectively, were used to estimate the total rolling stock fleet size in 2050. One limitation of the study is that the analysis has focussed on European cross-border freight transport movements and does not include the national transport chains since precise Origin-Destination (O/D) information was not available.

The EcoTransIT World (EcoTransIT, 2015) is an online tool for the calculation of energy consumption and emission data of a worldwide transport chain consisting of one or multiple modes of freight transport. The tool calculates environmental impacts i.e. emissions (e.g. $\mathrm{CO}_{2}$ ) of different carriers using a load factor (average use of vehicles maximum capacity) of typically $60 \%$. It may be argued that a $60 \%$ load factor is not realistic for rail freight transport because rolling stock that carries full loads often return empty and due to imbalances of trade and different cargoes often require another type of wagon. Hence a 50\% load factor (Islam, 2014b) might be more realistic. However considering the scope of the current research, we assume this $60 \%$ load factor as the base line of current rail freight productivity levels of wagons for rail freight transport. The various factors or methods (technical, operational, managerial) of improving (or decreasing) productivity are discussed in section 2.

In the absence of independent and verified productivity level data for the rail freight industry in general and rolling stock utilisation in particular, the current research conducts a sensitivity analysis to explore a variety of 
productivity levels (e.g. 50\%, 55\%, 65\% and 70\%) taking into account different factors, in calculating the number of rolling of rolling stock in 2050 using a form of sensitivity analysis.

The next step is to assign the current (2010) and future (2050) fleet size into major categories of rolling stock. This is performed by first producing proportions (out of 100\%) of cargo types calculated by analysing data from previous forecast: (D-RAIL, 2012a) and then assigning NSTR cargo types to rolling stock type. Thus the research identifies total rolling stock fleet size and types.

\section{Determining current fleet size of European rolling stock}

To determine the current fleet size of the European railway rolling stock, the research consulted, amongst others, the Eurostat Database; Railway Directory 2007 and 2012 and its online data source; the European Railway Agency website and DNV reports.

\subsection{Eurostat Database}

Firstly, in previous section we noted that the Eurostat database was appraised and data obtained through the following search path:

Transport > Railway Transport > Railway Transport Equipment > Number of wagons, by status of enterprise

This search query returned the results shown in Table 2 for the years 2001 to 2009. It should be noted that privately owned vehicles are not included in these statistics although a significant number of wagons are being handled by specific private initiatives and these private companies are steadily increasing. It can be seen in Table 2 that the total number of wagons reported varies greatly between 2001 and 2009. The variation is likely to be caused by a number of factors, namely: a lack of consistency in reporting by European countries year on year and the exclusion of private wagons in the data. The global economic downturn of 2008 is expected to have impacted negatively on the total number of wagons reported. It is probably true that due to longevity, existing wagons are less likely to disappear from the market but due to the recession there is lower requirement for freight activity resulting in lower demand and fewer wagons in operation. The recession is likely to affect the number of new wagons coming into operation. However the recession should not have had any influence on any statistical or reporting errors. Examining the 2009 data (the most comprehensive dataset) shows a total of 347,698 wagons. However there are a couple of very noticeable absentees from this list, not least, Germany, France and the UK who are the major players in the field. Populating these cells using an average increase/decrease of linear interpolation produces the last column $(* 2009)$ in Table 32.

Table 2: Number of rail freight wagons operating in the EU27 (Source Eurostat)

\begin{tabular}{|c|c|c|c|c|c|c|c|c|c|c|}
\hline GEO/TIME & 2001 & 2002 & 2003 & 2004 & 2005 & 2006 & 2007 & 2008 & 2009 & *2009 \\
\hline Belgium & 19,719 & 20,312 & 20,101 & 18,782 & 17,077 & 15,544 & 15,730 & 15,854 & 12,821 & 12,821 \\
\hline Bulgaria & 22,925 & 14,537 & 13,505 & 12,317 & & & & & 11,812 & 11,812 \\
\hline Czech Repl & 52,427 & 49,150 & 48,158 & 47,500 & 47,172 & 47,680 & 47,659 & 46,925 & 35,436 & 35,436 \\
\hline Denmark & 1,746 & 1,378 & & & & 192 & 153 & 0 & & \\
\hline Germany (i) & 118,415 & 111,852 & & & 102,778 & & & & & 87,549 \\
\hline Estonia & 6,122 & 7,531 & 17,433 & 18,924 & 18,376 & 18,376 & 16,781 & 19,643 & 18,284 & 18,284 \\
\hline Ireland & 1,817 & & & & & & & & & \\
\hline Greece & 3,539 & 3,535 & 3,473 & 3,497 & 3,204 & 3,166 & 3,568 & 4,763 & & 3,996 \\
\hline Spain & 25,987 & 25,041 & & 32,658 & 22,658 & 13,817 & 14,311 & 13,718 & 13,218 & 13,218 \\
\hline France & 109,770 & 107,033 & 103,833 & 99,372 & 95,238 & & & & & 81,014 \\
\hline Italy & & & 56,155 & 54,528 & 45,660 & 46,371 & 41,398 & 40,740 & 30,319 & 30,319 \\
\hline Latvia & 8,105 & 7,911 & 7,952 & 8,706 & 8,871 & 8,848 & 8,891 & 8,796 & 9,493 & 9,493 \\
\hline Lithuania & 12,509 & 12,391 & 12,144 & 13,134 & 13,192 & 13,393 & 13,564 & 13,918 & 13,792 & 13,792 \\
\hline Luxembourd & & & & & & 3,450 & 3,650 & 3,650 & & 3,783 \\
\hline Hungary & 22,983 & 21,695 & 20,189 & 19,783 & 16,027 & & & 12,240 & 10,683 & 10,683 \\
\hline \multicolumn{11}{|l|}{ Netherlands } \\
\hline Austria & 18,519 & 18,441 & & & & & 20,787 & & & 21,558 \\
\hline Poland & 96,741 & 119,308 & 111,532 & 107,315 & 103,234 & 103,527 & 104,982 & 101,528 & 95,462 & 95,462 \\
\hline Portugal & 4,366 & 4,092 & & & & & & 3,043 & & 2,852 \\
\hline Romania & 93,187 & 86,786 & & 60,964 & 58,951 & 55,503 & 54,713 & 47,420 & 45,505 & 45,505 \\
\hline Slovenia & 5,981 & 5,774 & 4,770 & 4,627 & 4,465 & 4,508 & 4,501 & 4,476 & 4,374 & 4,374 \\
\hline Slovakia & 24,587 & 24,796 & 23,973 & 24,936 & 25,515 & 25,989 & 27,538 & 20,820 & 14,534 & 14,534 \\
\hline Finland & 12,259 & 11,842 & 11,627 & 11,738 & 11,216 & 11,024 & 10,848 & 10,992 & 10,524 & 10,524 \\
\hline Sweden & 17,910 & 17,674 & 16,909 & 16,832 & 16,637 & 16,407 & 15,896 & 15,735 & 14,797 & 14,797 \\
\hline \multicolumn{11}{|l|}{ United King } \\
\hline Norway & 631 & & & & & & & & & \\
\hline \multicolumn{11}{|l|}{ Switzerland } \\
\hline Croatia & 9,456 & 8,774 & 7,920 & 7,376 & 7,330 & 6,813 & 6,781 & 6,632 & 6,644 & 6,644 \\
\hline Total & 91,701 & 679,853 & 479,674 & 562,989 & 617,601 & 394,608 & 411,751 & 390,893 & 334,245 & 48,450 \\
\hline
\end{tabular}


It can be seen that the revised total for year 2009 is equal to 548,450 wagons. Whilst Eurostat should be considered the official source for European statistics it is quite clear that in this instance the reporting methods are inadequate and lack the consistency required to be used as a base of evidence for this research. Considering the uncertainty in this approach it was considered important to investigate alternative data sources.

\subsection{Railway Directory}

The Railway Directory is the international rail industry reference work, covering operators, statutory bodies, manufacturers, suppliers and services. The first edition was published in 1895. The current website (accessed subject to a subscription fee and consulted in 2012) was redeveloped in early 2009 and went live in September 2009 - although the content is updated most days. The directory allows organisations and bodies with the appropriate subscription to access a variety of data including freight and passenger operating data. With this in mind a thorough review of rail freight operators and their rolling stock was conducted by collecting data from two year books: (Railway Directory, 2007, 2012). Specifically, the data:

- $\quad$ ranged from 2003-2011

- $\quad$ did not include states, Cyprus, Estonia and Malta

- $\quad$ provided data for wagons, electric locos, diesel locos and shunters

- $\quad$ included 369 companies and organisations

- $\quad$ was not classified by year for 187 of the 369 organisations

The railway directory indicated 463,626 wagons were present in the EU27 excluding Cyprus, Estonia and Malta for which data was not available. It is the range of years that provided most cause for concern regarding the reliability of the dataset. As mentioned previously, 187 of the organisations did not have a corresponding year. This equated to 22092 wagons with no associated year. Considering the uncertainty in this approach it was considered important to again investigate an alternative data source.

\subsection{DNV Report}

The DNV report (European Railway Agency, 2011a, 2011b) entitled "Assessment of freight train derailment risk reduction measures" was divided into two distinct research stages: Parts A and B. Part A aimed at identifying all prevention and mitigation measures that exist today or could be implemented within the short term (before 1st of January 2013) or medium term (ready to be voluntarily applied or to be introduced in EU regulation within 5 to 10 years). Part B had the objective of analysing the measures identified in Part A with a view to identifying those that were the most efficient. Part B included all prevention measures but was limited to mitigation measures based on derailment detection. The scope was directed towards identifying preventive and mitigation measures related to freight train operation. Shunting or marshalling operations were not considered to the same degree. The geographical scope for this work considered the EU-27 countries plus the 3 candidate countries (Turkey, Macedonia and Croatia) and two EEA countries Norway and Switzerland. In addition, the USA and Japan were considered in the scope of safety measure identification, but limited to the most commonly used safety measures and to the foreseeable innovations at medium term. As part of the DNV report a comprehensive review of mitigation measures was conducted. The review included the development of a cost model and economic assessment of these measures. With reference to mitigation measures it can be seen that the report (European Railway Agency, 2011a) identifies a total 718,000 rail freight wagons for the year 2009 within the geographical scope described previously.

This figure $(718,000)$ is also referenced in the Final Report entitled "Prevention and mitigation of freight train derailments at short and medium terms" (European Railway Agency, 2012). The DNV report was also widely used (e.g. to identify, breakdown and classification of rail train derailment causes) as a reliable source by previous D-RAIL studies (D-RAIL, 2012b, 2012c). Considering the pros and cons of all of the above sources of data, the authors consider the DNV report to be a suitable source of information for this study.

The current research assumes 2010 as a base year. Through this consultation process, the authors assume a fleet size of 718,000 wagons. As with any forecast there is a degree of uncertainty, particularly for long term forecasts like the one explored in this research. Considering the ambitious nature of the EU White Paper 2011 objectives on modal shift from road to rail freight transport, and the reluctance of the rail industry to embrace change (e.g. the application of new technology or the slow adoption of logistics concepts such as door-to-door services), a wholly new approach to asset management sensitivity tests were undertaken. The sensitivity analysis assumes a variety of changes in rail freight productivity (positively and negatively) and explores the effects on the rail freight rolling stock fleet size. 


\section{Determining future fleet size of European rolling stock}

\subsection{Rolling Stock Forecast Assumptions}

This section aims to assess and estimate the total EU27 rolling stock fleet size in 2050 based on the freight forecast reported by Islam, et.al. (2015). The fleet size for a year is calculated using average annual growth rate (see Table 3) multiplied by the fleet size in previous year. It can be noted that some of the rolling stock is used exclusively while others are used infrequently. For the purposes of this analysis it is assumed that all rolling stock is utilised and used consistently. This assumption allows an average tonne-kilometre (TKM) per wagon value to be applied to the commodity forecast.

As average load factor of $60 \%$ is used meaning that a wagon is on average $60 \%$ full. This load factor is therefore the starting point for the sensitivity testing, which assumes that increased load factors and improvements in wagon efficiency will occur in the future. Assuming a fixed load factor we assume a doubling in the transport of goods by rail will result in a doubling of the wagon fleet size. As noted in Table 1, certain commodity groups are assumed to be transported by certain wagon types.

\subsection{Fleet size determination approach}

For each of the scenarios the freight volume in billion TKM and percentage annual growth rates for different years are shown in Table 33

Table 3: Rail freight demand in billion tonne kilometres (BTKM)

\begin{tabular}{|l|l|l|l|l|}
\hline Scenario/ year & 2010 & 2030 & 2050 & $\begin{array}{l}\text { pa } \\
\text { growth }\end{array}$ \\
\hline REF - Business as usual (Reference) & 316 & 439 & 521 & $1.26 \%$ \\
\hline WPL - White Paper Low & 316 & 488 & 611 & $1.66 \%$ \\
\hline WPH - White Paper High & 316 & 699 & 1000 & $2.92 \%$ \\
\hline
\end{tabular}

Source: Islam, at al. (2015)

Based on an examination of trends and a thorough and comprehensive modelling process Islam, et al. (2015) anticipated that there will be very significant increases in demand for rail freight services should the European Commission meet its targets for modal shift from road to rail and inland waterways. The growth rates in column 6 of Table 3 are applied to determine the rolling stock fleet size for 2050.

\subsection{Fleet size without changes in productivity}

Having explained the approach adopted during the course of this analysis the overall results (in terms of rolling stock fleet size in 2030 and 2050) are now presented for three forecasting scenarios (REF, WPL and WPH). The analysis estimated the following wagon fleet for the EU27 and CH:

- $\quad 1,095,963$ wagons in 2050 assuming "Business as usual" scenario i.e. REF

- $\quad 1,283,168$ wagons in 2050 assuming the partially implementation of White Paper targets i.e. WPL

- $\quad 2,100,247$ wagons in 2050 assuming the full implementation of White Paper objectives i.e. WPH

Table 4: Rolling stock fleet size without changes in productivity level

\begin{tabular}{|l|l|l|}
\hline Scenario & Fleet size in 2030 & Fleet size in 2050 \\
\hline REF - Business as usual & 853,174 & $1,095,963$ \\
\hline WPL - White Paper Low & 923,169 & $1,283,168$ \\
\hline WPH - White Paper High & $1,181,068$ & $2,100,247$ \\
\hline
\end{tabular}

It can be noted that these figures (see Table 44) assume no change in efficiency or load factors (i.e. $60 \%$ ) for rail freight between 2010 and 2050. So the next step is to conduct sensitivity analysis using varying $( \pm 5 \%$ and \pm $10 \%)$ productivity levels.

\subsection{Impact of increased/decreased productivity on overall fleet size}

The current research explores the effect of significant $(5 \%-25 \%)$ changes in productivity to the number of wagons in operation. The first step in the sensitivity testing is to examine the effect of changes to the load factor (currently assumed 60\%) to the total rolling stock number for 2050. The results of these tests can be seen in Table 5 and Table 6 below for the three forecasting scenarios. 
Table 5: The European Railway rolling stock fleet size in 2030 with $+/-5 \%$ and $+/-10 \%$ productivity variation

\begin{tabular}{|l|l|l|l|l|}
\hline Scenario & $+5 \%$ & $+10 \%$ & $-10 \%$ & $-5 \%$ \\
\hline REF - Business as usual & 810,515 & 767,857 & 938,491 & 895,833 \\
\hline WPL - White Paper Low & 877,011 & 830,852 & $1,015,486$ & 969,327 \\
\hline WPH - White Paper High & $1,122,015$ & $1,062,961$ & $1,299,175$ & $1,240,121$ \\
\hline
\end{tabular}

Table 6: The European Railway rolling stock fleet size in 2050 with $+/-5 \%$ and $+/-10 \%$ productivity variation

\begin{tabular}{|l|l|l|l|l|}
\hline Scenario & $+5 \%$ & $+10 \%$ & $-10 \%$ & $-5 \%$ \\
\hline REF - Business as usual & $1,041,165$ & 986,367 & $1,205,559$ & $1,150,761$ \\
\hline WPL - White Paper Low & $1,219,009$ & $1,154,851$ & $1,411,485$ & $1,203,126$ \\
\hline WPH -White Paper High & $1,995,235$ & $1,890,222$ & $2,310,272$ & $1,976,406$ \\
\hline
\end{tabular}

\section{Rolling stock type}

\subsection{Wagon type requirement in in 2050}

Using the freight forecast data from the D-RAIL (2012a) we calculate the freight volume for the year 2050 per NSTR commodity and determine the net growth which can be defined as the difference in forecast volumes per commodity between 2010 and 2050. This provides input for determining wagon type requirements in 2050. For example, in the REF scenario, the volume of solid mineral fuels is calculated at 95.7 billion TKM in 2050 minus 48.1 billion TKM in 2010 equating to a Net Growth of 47.6 billion TKM (see Table 7). In this way we calculate the net freight volume for all commodity groups and then link with the wagon type noted in Table 1 for all three scenarios. Table 7 displays the prominent wagon type in 2050 for all three scenarios.

For the REF scenario, calculating the net growth in billion TKM for all commodity groups, it is apparent that three NSTR commodity types: crude, manufacturing and building materials; solid mineral fuels; and machinery and transport equipment will be the most significant commodity types in 2050 . The growth of inter-modal traffic (Machinery, transport equipment), which falls into the latter category, may prove to be understated if maritime and international inter-modal traffic from/to non-EU countries is included. Linking this freight volume forecast and Table 1 it is clear that solid mineral fuels are typically transported by Open top wagons with the option of an alternative wagon type: Covered hoppers. Crude, manufacturing and building materials are also typically transported in Open top wagons with the option of alternative wagon type: Flat wagon, Covered wagon and Tank wagon. The machinery and transport equipment are transported by Flat wagon with the option of alternative wagon: Special Flat wagons and Car carriers for finished vehicles and components. We therefore conclude that open top wagons and Flat wagons are most likely to feature in 2050 rail freight transport services when considering the Reference Scenario.

Table 7: Wagon Type requirement and forecasted net growth volume in billion TKM in Europe in 2050

\begin{tabular}{|l|l|l|l|l|}
\hline Commodity & Wagon Type & REF 2050 & WPL 2050 & WPH2050 \\
\hline Agricultural products & Covered Hopper Wagons & 13.1 & 23.0 & $\mathbf{7 4 . 2}$ \\
\hline Foodstuffs & Covered Wagon & 1.9 & 7.4 & 68.3 \\
\hline Solid mineral fuels (Coal) & Open Top Wagons & $\mathbf{4 7 . 6}$ & $\mathbf{4 8 . 6}$ & 50.9 \\
\hline Petroleum products & Tank Wagon & 9.2 & 11.0 & 19.9 \\
\hline Ores and metal waste & Open Top Wagons & 19.4 & 22.7 & 29.8 \\
\hline Metal products & Flat Wagons & 12.2 & 16.9 & 40.8 \\
\hline $\begin{array}{l}\text { Crude, manufacturing, } \\
\text { building materials }\end{array}$ & $\begin{array}{l}\text { Flat Wagons or Covered } \\
\text { Wagon }\end{array}$ & $\mathbf{5 2 . 6}$ & $\mathbf{7 6 . 8}$ & $\mathbf{1 4 6 . 5}$ \\
\hline Fertilizers & Covered Hopper Wagons & 14.4 & 15.1 & 19.4 \\
\hline Chemicals & Tank Wagon & 10.7 & 20.3 & 57.9 \\
\hline $\begin{array}{l}\text { Machinery, transport } \\
\text { equipment }\end{array}$ & Flat Wagon & $\mathbf{2 6 . 9}$ & $\mathbf{5 7 . 9}$ & $\mathbf{1 8 5 . 4}$ \\
\hline
\end{tabular}

N.B. The data in column 3, 4 and 5 are calculated from previous forecast: (D-RAIL, 2012a)

For the WPL, the most prominent commodity types are: crude, manufacturing and building materials; machinery and transport equipment and solid mineral fuels solid mineral fuels. As in the REF scenario, open top wagons and Flat wagons are most likely to feature in 2050 rail freight transport services when considering the WPL Scenario. 
For WPH, three commodity types feature in net growth in billion TKM in 2050: machinery and transport equipment; crude, manufacturing and building materials; and agriculture products. The volume of foodstuffs; will also be prominent. The foodstuffs are traditionally transported by covered wagons. Considering the diversity of foodstuffs including sugar, molasses, milk products; alternative wagon types may include Flat wagon (Refrigerated container/tanker). Covered Hopper wagons may feature for agriculture commodity types in 2050 with the option of alternative wagon types: Open top wagon. Flat wagon may feature for machinery and transport equipment commodity type with the option of alternative wagons: Special Flat wagon and Car carriers.

Table 8: Rolling stock fleet types without changes in productivity level

\begin{tabular}{|l|r|l|l|l|l|}
\hline Wagon type & Proportion of & Fleet in 2010 & REF 2050 & WPL 2050 & WPH 2050 \\
\hline Covered Hopper Wagons & $13.14 \%$ & 94,317 & 144,375 & 165,820 & 281,437 \\
\hline Covered Wagon & $1.21 \%$ & 8,696 & 12,398 & 23,798 & 150,334 \\
\hline Open Top Wagons & $26.23 \%$ & 188,359 & 303,442 & 311,804 & 331,171 \\
\hline Tank Wagon & $10.42 \%$ & 74,791 & 111,838 & 135,240 & 231,084 \\
\hline Flat Wagons & $49.00 \%$ & 351,837 & 523,911 & 646,506 & $1,106,220$ \\
\hline Total & $100.00 \%$ & $\mathbf{7 1 8 , 0 0 0}$ & $\mathbf{1 , 0 9 5 , 9 6 3}$ & $\mathbf{1 , 2 8 3 , 1 6 8}$ & $\mathbf{2 , 1 0 0 , 2 4 7}$ \\
\hline
\end{tabular}

N.B. The proportion in column 2 is calculated from data from previous forecast: (D-RAIL, 2012a) by assigning NSTR cargo types to rolling stock type. Subsequently the proportion is used to assess individual rolling stock fleet in remaining columns.

Considering all three scenarios, the study's findings clearly suggest that the Flat wagon (see Table 8) will be prominent in 2050 rail freight. In the case of WPH, the requirement of Flat wagon will be even much more significant. The second clear type of wagon requirement will be the covered wagon Covered Hopper Wagon (see Table 7-8) in particular in the WPH. It is also envisaged that the Open top wagon will remain prominent as well in all three scenarios.

\subsection{Trend of rail cargo units in Europe}

The 'Consignment' in Figure 3 (vertical axis) is equivalent to 2.0 TEU (twenty foot equivalent unit), meaning: one semi-trailer; or two swap bodies less than $8.30 \mathrm{~m}$ and under 16 tonnes; or one swap-body more than $8.30 \mathrm{~m}$ or over 16 tonnes; or one vehicle on the Rolling Motorway. Rolling motorway (or rolling road) can be defined as a form of combined transport (CT), which involves carriage of complete trucks, truck tractors with trailers and trucks with semi-trailers (ADRIA KOMBI, 2013). They also suggest that its alternative terminology is 'accompanied transport' for such CT where the drivers drive their vehicles onto freight wagons and then accompany them on the same train in a special passenger wagon. From Figure 3 we can say that among the three types of cargo units transported by rail, it is evident that there is a decline in semi-trailers and rolling motorway and increase in the percentage of swap bodies. So the future rolling stock in 2030 and 2050 may take note of such a trend. With the findings so far and consulting the UIC leaflets on wagon type, we can say that more Flat wagons will be required in 2030 and 2050.

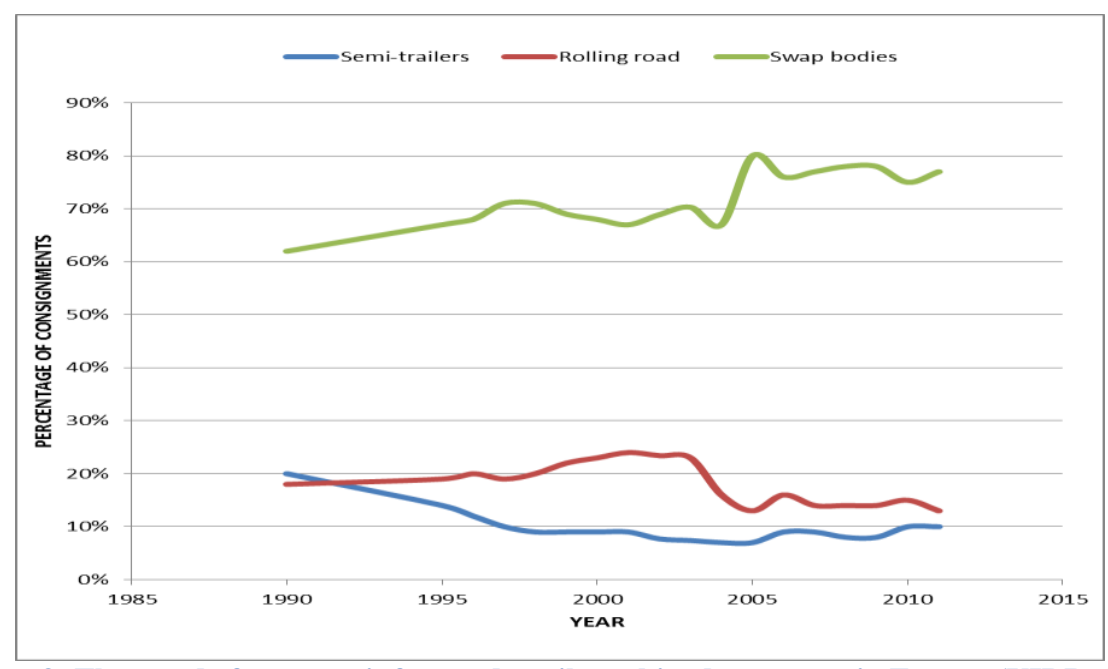

Figure 3: The trend of cargo unit for road - rail combined transport in Europe (UIRR, 2013) 


\section{Summary}

This research has combined qualitative and quantitative methods in order to estimate the anticipated rolling stock fleet size in the year 2050. This study has been driven by the European Commission's 2011 Transport White Paper which sets ambitious targets for modal shift from road to more sustainable modes of transport such as rail. Based on these targets the research developed three scenarios: Business as usual (Reference), WPL - White Paper Low (partial implementation/achievement of the targets) and WPH - White paper high (full implementation/achievement of the targets) reflecting the ambitious nature of the targets and their likely realization. We think that at least one of two things must happen in terms of rail freight rolling stock fleet size and type should these objectives be met. Firstly, significantly more rolling stock will be required to facilitate the increased volume and/or secondly, rail freight must significantly improve its productivity to lessen the 'significantly more' number of rolling stock. Based on the forecasting scenarios the study estimates that:

- $1,095,963$ wagons will be required in 2050 in the "Business as usual" scenario;

- $1,283,168$ wagons will be required in 2050 for the partial implementation of EC 2011 White Paper policy objectives; and

- 2,100,247 wagons will be required in 2050 for the full implementation of EC 2011 White Paper policy objectives.

Beyond this, the research also estimated those wagon types anticipated to feature most prominently in 2050 based on the commodity type likely to be transported by rail in 2050 . The research finds that flat wagons, covered wagons and covered hopper wagons will form a significant part of the railway rolling stock in 2050 .

\section{Conclusion and Recommendation}

This research reveals that the owners and operators of railway rolling stock (freight wagons) had what might be described as a relaxed attitude to asset management. This was reflected by the challenge the authors faced in obtaining data on rolling stock fleet size. Despite the enormous expense (capital and maintenance) of rail wagons they are rarely treated as a valuable asset. In response to the intense competition from road and changes in the cargo typologies (i.e. demand), increasingly there is a desire to manufacture wagons such that their working life is increased, in line with the policy of 'higher value for money'. This is advantageous in terms of operational and unit cost over the life of the vehicle, however it has the negative effect of slow uptake of development and innovation in the railways transport sector. In section 2.1.1 we noted that when comparing rail and road, the working life of a railway wagon is much higher than a road vehicle (truck). This shorter life span of road vehicles facilitates a more rapid introduction of new technologies and innovations. The challenge is how a balance can be made so that the manufacturers and users of future rolling stock can achieve 'value for money' on the investment in the new rolling stock but at the same time accommodate future technical and operation development and innovation.

Over the last forty years the rail freight market share has steadily declined and it is a real challenge to turn the modal shift aspirations of the Transport White Paper 2011 into a reality. Indeed it will require a step change (like that occurred in the US rail sector in 1980, discussed in section 2.4) in service and this step change will require the introduction of new technologies, not only limited to the vehicle but extended to include the infrastructure as well as a unified rail corridor. Recently completed studies such as European Commission (2014a, 2014c, 2014d, 2014e) on nine rail freight corridors (RFCs) have identified critical issues, gaps, and investment needs. Such step changes require a coordinated and huge investment at national and European level which remains a challenge. The development of well-equipped terminals along the nine RFCs hope to facilitate modal shift to rail. Once the RFCs are fully operation, the co-operation between the rail freight operators (e.g. sharing information on free wagon-space), will be vital.

The intentions of the European Commission and other funding bodies are certainly laudable however previous initiatives have had little effect in addressing the overall challenge of modal shift. This may be partly due to the fact that the road industry is not sitting idle but is adopting and implementing new R\&D strategies of its own (e.g. Green Cars http://ec.europa.eu/research/transport/road/green_cars/index_en.htm). It should also be noted that whilst the design and implementation of innovative vehicles and technologies will doubtless overcome some challenges it will do little to overcome the limitations of the current railway infrastructure. The EC realises this and hopes to address these challenges by better utilizing existing capacity. Previous initiatives have provided an evidence base for further work and the hope is that future measures will achieve the final percentage required to facilitate a significant modal shift. 
The likely implication of the current research is that the rail freight operators, wagons manufacturers and companies involved in leasing and hiring wagons, as well as representative bodies such as the Union of European Railway Industries (UNIFE), Communities of European Railways (CER), International Union for Road-Rail Combined Transport (UIRR) and above all the SHIFT2RAIL initiative will have to take note of the research outcome and will prepare themselves, by acquiring suitable rolling stock fleet, to meet the demands of customers in 2030, 2050 and beyond.

\section{Acknowledgement}

The authors thank the European Commission for part-funding the research under the seventh Framework Programme, within the projects D-RAIL - "Development of the Future Rail Freight System to Reduce the Occurrences and Impact of Derailment" (Grant Agreement No: 285162FP7-THEME [SST.2011.4.1-3]). The authors would also like to thank D-RAIL consortium partners and the anonymous peer reviewers for their invaluable constructive criticisms that significantly enriched the quality of the research. The content and the opinions expressed in this article are the full responsibility of the authors.

\section{References}

ADRIA KOMBI. (2013). Rolling Motorway. Retrieved January 1, 2013, from http://www.adriakombi.si/

AssociationofAmericanRailroads. (2014). An Overview of America's Freight Railroads.

Bärthel, F., \& Woxenius, J. (2004). Developing intermodal transport for small flows over short distances. Transportation Planning and Technology, 27(5), 403-424. doi:10.1080/0308106042000287586

Bontekoning, Y., \& Priemus, H. (2004). Breakthrough innovations in intermodal freight transport. Transportation Planning and Technology, 27(5), 335-345. doi:10.1080/0308106042000273031

Boyer, K. D. (2014). Why is the Rail Share of US Freight Traffic So Low? Journal of Transport Economics and Policy, 48(Part 2), 333-344.

Boysen, H. (2012a). General model of railway transportation capacity. In 13th International Conference on Design and Operation in Railway Engineering (Comprail). doi:10.2495/CR120281

Boysen, H. (2012b). presentation of the paper titled General model of railway transportation capacity. In 13th International Conference on Design and Operation in Railway Engineering (Comprail) (Vol. 127, pp. 335-347). doi:10.2495/CR120281

Boysen, H. (2013). ØRESUND AND FEHMARNBELT HIGH-CAPACITY RAIL CORRIDOR STANDARDS. In 10th International Railway Engineering Conference (pp. 1-27). London: ECS Publication.

Boysen, H. (2014). Øresund and Fehmarnbelt high-capacity rail corridor standards updated. Journal of Rail Transport Planning \& Management, 4(3), 44-58. doi:10.1016/j.jrtpm.2014.09.001

Capacity4Rail Project. (2014). Requirements toward the freight system of 2030/2050 - Intermediate report, Deliverable 21.1 .

Clausen, U., Doll, C., Franklin, F. J., Franklin, G. V., Heinrichmeyer, H., Kochsiek, J., ... Sieber, N. (2012). Reducing Railway Noise Pollution.

Community of European Railway and Infrastructure Companies. (2013). Rail Freight Status Report 2013 Rail Freight After a Decade of EU Rail Policy. Retrieved from http://www.cer.be/

Community of European Railway and Infrastructure Companies. (2014a). Annual Report 2013-2014. Brussels.

Community of European Railway and Infrastructure Companies. (2014b). CER Policy Priorities for the 2014 2019 Mandate. 
Danielis, R., \& Marcucci, E. (2007). Attribute cut-offs in freight service selection. Transportation Research Part E: Logistics and Transportation Review, 43(5), 506-515. doi:10.1016/j.tre.2005.10.002

Den Boer, E., van Essen, H., Brouwer, F., Pastori, E., \& Moizo, A. (2011). Potential of modal shift to rail transport Study on the projected effects on GHG emissions and transport. Delft: Community of European Railway and Infrastructure Companies (CER).

Department for Transport. (2011). Realising the Potential of GB Rail Final Independent Report of the Value for Money Study. London. doi:May

D-RAIL. (2012a). Rail Freight Forecast to 2050. Newcastle upon Tyne: NewRail, Newcastle Centre for Railway Research, Newcastle University.

D-RAIL. (2012b). Report on Derailment Economic Impact Assessment, D-RAIL Deliverable D1.2. Retrieved from http://publik.tuwien.ac.at/files/PubDat_210278.pdf

D-RAIL. (2012c). Summary report and database of derailments incidents, D-RAIL Deliverable D 1.1.

EcoTransIT. (2015). EcoTransITWorld. CALCULATION. Retrieved March 27, 2015, from http://ecotransit.org/

European Commission. (2009). A sustainable future for transport: Towards an integrated, technology-led and user friendly system (No. COM/2009/0279 final.). Brussels.

European Commission. (2011). Transport White Paper - Roadmap to a Single European Transport Area Towards a competitive and resource efficient transport system. Brussels: European Commission. doi:COM(2011)144

European Commission. (2014a). Baltic-Adriatic Core Network Corridor Study.

European Commission. (2014b). EU Transport in Figures - Statistical pocketbook 2014. Retrieved from http://ec.europa.eu/transport/facts-fundings/statistics/pocketbook-2014_en.htm

European Commission. (2014c). Mediterranean Core Network Corridor Study Final report.

European Commission. (2014d). North Sea-Baltic Core Network Corridor Study.

European Commission. (2014e). Scandinavian-Mediterranean Core Network Corridor Study.

European Commission. (2014f). Transport: European Parliament adopts equivocal first reading position on fourth railway package. Press Release Databse. Retrieved from http://europa.eu/rapid/press-release_IP-14192_en.htm

European Railway Agency. (2011a). Assessment of freight train derailment risk reduction measures : B2 - Risk model and potential effectiveness of measures. 120 rue Marc Lefrancq, 59300 Valenciennes, France.

European Railway Agency. (2011b). DNV Report on Assessment of freight train derailment risk reduction measures: Part A Existing Measures Final Report. 120 rue Marc Lefrancq, 59300 Valenciennes, France, 21 July.

European Railway Agency. (2012). Prevention and mitigation of freight train derailments at short and medium terms.

Ferreira, L. (1997). Planning Australian freight rail operations: An overview. Transportation Research Part A: Policy and Practice, 31(4), 335-348. doi:10.1016/S0965-8564(96)00026-2

Ferreira, L., \& Murray, M. H. (1997). Modelling rail track deterioration and maintenance: current practices and future needs. Transport Reviews, 17(January 2015), 207-221. doi:10.1080/01441649708716982 
Fröidh, O. (2014). Design speed for new high speed lines. Journal of Rail Transport Planning \& Management, 4, 24p. doi:10.1016/j.jrtpm.2014.09.002

Gwangwar, R., \& Raghuram, G. (2014). Framework for structuring public private partnerships in railways. Case Studies on Transport Policy. doi:10.1016/S2213-624X(13)00011-4

Hesse, M., \& Rodrigue, J.-P. (2004). The transport geography of logistics and freight distribution. Journal of Transport Geography, 12(3), 171-184. doi:10.1016/j.jtrangeo.2003.12.004

Hilmola, O.-P. (2008). Railway Wagon Market Analysis and New Multi-Purpose Wagon Solution for Freight Transports - Finnish Manufacturing Perspective Railway Wagon Market Analysis and New Multi-Purpose Wagon Solution for Freight Transports - Finnish Manufacturing Perspective.

Houldin, C., Clarke, G., \& Murphy, P. (2012). ORR Freight Customer Survey 2012 Final Report. doi:Job no 60263407

International Transport Forum. (2013). Railway Efficiency An Overview and a Look at Opportunities for Improvement (No. 2013-12).

Islam, D. (2014a). BARRIERS TO AND ENABLERS FOR EUROPEAN RAIL FREIGHT TRANSPORT FOR INTEGRATED DOOR-TO-DOOR LOGISTICS SERVICE . PART 1 : BARRIERS TO MULTIMODAL RAIL FREIGHT TRANSPORT. TRANSPORT PROBLEMS, 9(3).

Islam, D. (2014b). BARRIERS TO AND ENABLERS FOR EUROPEAN RAIL FREIGHT TRANSPORT FOR INTEGRATED DOOR-TO-DOOR LOGISTICS SERVICE . PART 2 : ENABLERS FOR MULTIMODAL RAIL FREIGHT TRANSPORT KOLEJ Ą DO ZINTEGROWANEJ OBS Ł UGI LOGISTYCZNEJ DOOR-TO-DOOR . TRANSPORT PROBLEMS, 9(4).

Islam, D., \& Eidhammer, O. (2015). Advances in the competitiveness of pan-European rail freight services: findings from a case study. $R \& D$ Management.

Islam, D., Jackson, R., Zunder, T., \& Burgess, A. (2015). Assessing the impact of the 2011 EU Transport White Paper - a rail freight demand forecast up to 2050 for the EU27. European Transport Research Review, 7(77), 1-9. doi:10.1007/s12544-015-0171-7

Islam, D., Jackson, R., Zunder, T., Laparidou, K., \& Burgess, A. (2013). Triple rail freight demand by 2050 in EU27- realistic, optimistic or farfetched imagination? In 10th World Congress on Railway Research. Sydney, Australia.

Islam, D., Zunder, T., \& Zomer, G. (2010). The potential of a pan European rail freight service using hub and spoke model. International Journal of Logistics and Transport, 4(2), 21-30.

Jackson, R., Islam, D., Zunder, T., Schoemaker, J., \& Dasburg, N. (2014). A market analysis of the low density high value goods flows in Europe. In: Selected Proceedings: 13th World Conference on Transport Research (WCTR). 2014, Rio de Janeiro: COPPE - Federal University of Rio de Janeiro, Brazil., In: Select, 1-12.

Jackson, R., Matsika, E., Zunder, T., \& Mahler, S. (2013). Conceptualisation of an Innovative Rail Freight Vehicle for Transporting LDHV Cargo in an EU Context. In WCRR Sydney.

K+P Transport Consultants and Fraunhofer ISL. (2011). Study on the Effects of the Introduction of LHVs on Combined Road-Rail Transport and Single Wagonload Rail Freight Traffic Executive Summary (Vol. 49).

Kallas, S. (2013). EUROPEAN RAILWAYS AT A JUNCTION: THE COMMISSION ADOPTS PROPOSALS FOR A FOURTH RAILWAY PACKAGE. European Commission website. Retrieved from http://ec.europa.eu/commission_2010-2014/kallas/headlines/news/2013/01/fourth-railway-package_en.htm

Kallas, S. (2014). European Commission unhappy with Fourth Railway package vote. Global RailNews. Retrieved March 27, 2015, from http://www.globalrailnews.com/blog/2014/03/04/european-parliamentunhappy-with-fourth-railway-package-vote/ 
Krüger, N., \& Vierth, I. (2015). Precautionary and operative costs of freight train delays : a case study of a Swedish grocery company. European Transport Research Review, 1-10. doi:10.1007/s12544-015-0155-7

Link, H. (2004). Rail infrastructure charging and on-track competition in Germany. International Journal of Transport Management, 2(1), 5-15. doi:10.1016/j.ijtm.2004.05.002

Link, H. (2012). Unbundling, public infrastructure financing and access charge regulation in the German rail sector. Journal of Rail Transport Planning and Management, 2(3), 63-71. doi:10.1016/j.jrtpm.2013.02.002

Lochma, L. (2012). European Rail Network for competitive Freight - EU Regulation 913 / 2010 As customers , rail operators must be involved. In European Rail Freight Corridors Conference 10 May 2012, Frankfurt (pp. 1-11).

Lu, C., \& Yan, X. (2014). The break-even distance of road and inland waterway freight transportation systems. Maritime Economics \& Logistics, 17(2), 246-263. doi:10.1057/mel.2014.14

Malavasi, G., Molková, T., Ricci, S., \& Rotoli, F. (2014). Journal of Rail Transport Planning \& Management A synthetic approach to the evaluation of the carrying capacity of complex railway nodes. Journal of Rail Transport Planning \& Management, 4(1-2), 28-42. doi:10.1016/j.jrtpm.2014.06.001

Marathon Consortium. (2014). The Marathon Handbook - 1500m Train Opening up new horizons in Rail Freight Transport in Europe. (F. Castagnetti \& A. Toubol, Eds.). NEWOPERA Aisbl.

Marinov, M., Şahin, I., Ricci, S., \& Vasic-Franklin, G. (2013). Railway operations, time-tabling and control. Research in Transportation Economics, 41, 59-75. doi:10.1016/j.retrec.2012.10.003

Meixell, M., \& Gargeya, V. (2005). Global supply chain design: A literature review and critique. Transportation Research Part E: Logistics and Transportation Review, 41, 531-550. doi:10.1016/j.tre.2005.06.003

Morlok, E. K., Sammon, J. P., Spasovic, L. N., \& Nozick, L. K. (1995). Improving productivity in intermodal rail-truck transportation. In The Service Productivity and Quality Challenge (pp. 407-434).

Morlok, E. K., \& Spasovic, L. N. (1994). APPROACHES FOR IMPROVING DRAYAGE IN RAIL-T ... Page 1 of 35 APPROACHES FOR IMPROVING DRAYAGE IN RAIL-T ... Page 2 of 35. Retrieved from http://transportation.njit.edu/NCTIP/final_report/approaches_for_improving_drayage.htm

Mortimer, P., \& Islam, D. M. Z. (2014). A comparison of North American and European railway systems - a critique and riposte. European Transport Research Review. doi:10.1007/s12544-014-0148-y

Nash, C., Nilsson, J., \& Link, H. (2013). Comparing Three Models for Introduction of Competition into Railways. Journal of Transport Economics and Policy, 47(May), 191-206.

Nelldal, B., \& Boysen, H. (2012). Scandria Railway Corridor Performance, Baltic Sea Region Project \# 026. Stockholm.

Official Journal of European Union. Commission Regulation (EU) No 321/2013 of 13 March 2013 concerning the technical specification for interoperability relating to the subsystem "rolling stock - freight wagons" of the rail system in the European Union and repealing Decision 2006/861/EC (2013).

Park, Y., Choi, J. K., \& Zhang, A. (2009). Evaluating competitiveness of air cargo express services. Transportation Research Part E: Logistics and Transportation Review, 45(2), 321-334. doi:10.1016/j.tre.2008.09.004

Psaraftis, H. N. (ed). (2015). Transportation Logistics Associate Series Editor.

Pulfer, H., Timmermans, P., Crombruggen, K., Wildelau, M., Könnemann, B., Lehmann, E., \& Polito, F. (2014). Study Long Trains ( $740 \mathrm{~m}$ ) on Corridor Rotterdam-Genoa. 
Railway Directory. (2007). Statistics, People, Maps, Suppliers. Chippenham, SN15 1JD, UK: Railway Gazette Publication.

Railway Directory. (2012). Statistics, People, Maps, Suppliers. Railway Gazette Publication. Retrieved from www.railway directory.net

Reis, V. (2014). Analysis of mode choice variables in short-distance intermodal freight transport using an agentbased model. Transportation Research Part A: Policy and Practice, 61, 100-120.

doi:10.1016/j.tra.2014.01.002

Rowangould, G. (2013). Public financing of private freight rail infrastructure to reduce highway congestion: A case study of public policy and decision making in the United States. Transportation Research Part A: Policy and Practice, 57, 25-36. doi:10.1016/j.tra.2013.09.007

Salehi, F., Reinhold, T., \& Gasparic, C. (2009). Rail Freight : Returning to Profitability.

SCI/VERKEHR. (2014). EUROPEAN RAIL FREIGHT TRANSPORT MARKET 2014.

Shah, N., \& Brueckner, J. K. (2012). Price and frequency competition in freight transportation. Transportation Research Part A: Policy and Practice, 46(6), 938-953. doi:10.1016/j.tra.2012.02.014

SPECTRUM. (2012). Market based operational requirements for new rail freight services, Final Deliverable D1.2 (Vol. 2012). Newcastle upon Tyne. Retrieved from WWW.SPECTRUM.INFO

SPECTRUM. (2013). Deliverable D2.4 Concepts.

SUSTRAIL. (2015). A DESIGN GUIDE FOR SUSTAINABLE FREIGHT VEHICLE.

Törnquist, J., \& Gustafsson, I. (2004). Perceived Benefits of Improved Information Exchange - a Case Study on Rail and Intermodal Transports. Research in Transportation Economics, 8(04), 415-440. doi:10.1016/S0739-8859(04)08018-7

Toubol, A., \& Castagnetti, F. (2014). Marathon project for long trains with distributed traction. In Transport Research Arena 2014. Paris.

Troche, G. (2005). High-speed rail freight - Efficient train systems for freight transport. Stockholm.

Tsamboulas, D., Vrenken, H., \& Lekka, A. (2007). Assessment of a transport policy potential for intermodal mode shift on a European scale. Transportation Research Part A: Policy and Practice, 41(8), 715-733. doi:10.1016/j.tra.2006.12.003

UIC. (2001). Standard wagons - Ordinary bogie wagons - Characteristics UIC CODE 571-2 (6th ed.). UIC.

UIC. (2004a). Standard wagons - Special-purpose wagons - Characteristics UIC CODE 571-3 (6th ed.). UIC.

UIC. (2004b). Standard wagons Ordinary two-axle wagons - Characteristics UIC CODE 571-1 (5th ed.). UIC.

UIC. (2011). Standard wagons - Wagons for combined transport - Characteristics UIC CODE 571-4 (5th ed.). UIC.

UIRR. (2011, March). Recast of the First Railway Package. Press Release, (March), 2011. Retrieved from www.uirr.com

UIRR. (2013). UIRR Report on European Road-Rail Combined Transport 2012-2013.

Wiegmans, B. W., Hekkert, M., \& Langstraat, M. (2007). Can Innovations in Rail Freight Transhipment Be Successful? Transport Reviews, 27(1), 103-122. doi:10.1080/01441640600765091 
Woodburn, A. (2007). Appropriate indicators of rail freight activity and market share: A review of UK practice and recommendations for change. Transport Policy, 14(1), 59-69. doi:10.1016/j.tranpol.2006.09.002

Woroniuk, C., Marinov, M., Zunder, T. H., \& Mortimer, P. (2013). Time series analysis of rail freight services by the private sector in Europe. Transport Policy, 25(null), 81-93. Retrieved from http://dx.doi.org/10.1016/j.tranpol.2012.09.004

Yeo, G.-T., Roe, M., \& Dinwoodie, J. (2008). Evaluating the competitiveness of container ports in Korea and China. Transportation Research Part A: Policy and Practice, 42(6), 910-921. doi:10.1016/j.tra.2008.01.014

Zunder, T. H., Islam, D. M. Z., \& Mortimer, P. N. (2012). Pan-European Rail freight transport ; Evidence from a pilot demonstration result. Procedia - Social and Behavioral Sciences, 00(2011).

Zunder, T. H., Islam, D. M. Z., Mortimer, P. N., \& Aditjandra, P. T. (2013). How far has open access enabled the growth of cross border pan European rail freight? A case study. Research in Transportation Business \& Management, 6, 71-80. doi:10.1016/j.rtbm.2012.12.005 